\title{
Survey on the awareness of Schistosomosis infections in Gomboru - Ngala, North- Eastern Nigeria
}

\author{
A. A., Biu ${ }^{1}$, Gwana, A. M. ${ }^{2}$, Bako, M. M. ${ }^{3}$, Bassey, E. E. ${ }^{4}$, Bagudu, B. Y. ${ }^{5}$, Bukar-Kolo, Y. ${ }^{6}$, \\ Sadiq, A. B. ${ }^{7}$, Mustapha, U. M. ${ }^{8}$, Abdullahi, M. M. ${ }^{9}$ \\ ${ }^{1}$ Department of Veterinary Microbiology, Parasitology and Virology, Faculty of Veterinary Medicine, University of Maiduguri, Nigeria \\ ${ }^{2}$ LaboratoryUnit, A.H.P. Department, Mohamet Lawan College of Agriculture, P.M.B. 1427, Maiduguri, Nigeria \\ ${ }^{3}$ Department of Fisheries, Faculty of Agriculture, University of Maiduguri, P.M.B 1069, Maiduguri, Nigeria \\ ${ }^{4}$ Department of Microbiology, Nnamdi Azikwe University, Awka, Nigeria \\ ${ }^{5}$ Department of Science Laboratory Technology, Waziri Umaru Federal Polytechnic, Birnin Kebbi, Kebbi State, Nigeria \\ ${ }^{6}$ Department of Medicine, Faculty of Veterinary Medicine, Unimaid, Nigeria \\ ${ }^{7}$ Department of Biochemistry, University of Maiduguri, P.M.B. 1069, Maiduguri, Nigeria. \\ ${ }^{8}$ Department of Animal Health and Technology, Mohamet Lawan College of Agriculture, P.M.B. 1427, Maiduguri, Nigeria \\ ${ }^{9}$ Department of Basic Science, Mohamet Lawan College of Agriculture, P.M.B. 1427, Maiduguri, Nigeria
}

\section{Email address:}

biuvet@yahoo.com (A. A. Biu), admuwana@yahoo.com (Gwana, A. M.), mammadu09@gmail.com (Bako, M. M.), edetbassey69@gm.com (Bassey, E. E.), hutawas@yahoo.co.uk (Bagudu, B. Y.), yachillabukar@yahoo.com (Bukar, K. Y.), a.aji2k6@yahoo.com (Sadiq, A. B.), umarmarte@yahoo.com (Mustapha, U. M.), mumin_abdullahi@yahoo.com (Abdullahi, M. M.)

\section{To cite this article:}

A. A., Biu, Gwana, A. M., Bako, M. M., Bassey, E. E., Bagudu, B. Y., Bukar-Kolo, Y., Sadiq, A. B., Mustapha, U. M., Abdullahi, M. M.. Survey on the Awareness of Schistosomosis Infections in Gomboru - Ngala, North- Eastern Nigeria. European Journal of Preventive Medicine. Vol. 2, No. 5, 2014, pp. 69-80. doi: 10.11648/j.ejpm.20140205.12

\begin{abstract}
This research study was carried out on the survey on the awareness of Schistosomosis infections in Ngala Local Government Area, Borno, North Eastern Nigeria. The public awareness of the disease urinary or vesicle Schistosomosis (bilharzias) within the populace of the said communities has been determined. A total of 1000 respondents were involved, 572 (57\%) males and 428 (43\%) females, compound structured opened and closed ended questionnaires were administered randomly. The results obtained, revealed that, respondents under the age group of 9 to 18 years old are the highest in number while the least are 59 to 68 years old. Educational background; 44\% acquired Arabic and the least is $16 \%$ craft skills, most of them are farmers $35 \%, 24 \%$ were said to be practicing traditional treatment for Schistosomosis when infected, $48 \%$ said the sign and symptoms is presence of blood in urine, and from all indication only $17 \%$ said that they are aware of the disease bilharzias and $83 \%$ of the respondents were not aware of the disease, neither it's ways of contacting. There is no any relationship between the male and female respondents interviewed, when infected with the disease (bilharzias), they sort for traditional methods of treatment by using among common, are herbal concoctions and sour milk whey soaked with cornflakes as means of treatment. Only least numbers were patronizing clinics and hospitals for the proper treatment of the disease. Haemoparasitosis is endemic in tropical and sub tropical developing countries, including Nigeria; with Schistosomosis is seconded by Malaria are most common and very important childhood diseases and where sources of infection occur, especially, the Schistosom ahaematobium infection which is through contact with contaminated waters. The Government and or any authority concern should enlighten the populace of the communities on the awareness of the disease, Schistosomosi, its ways of infection, proper treatment and prevention. This is in order to control and eradicate the disease in this area.
\end{abstract}

Keywords: Awareness, Communities, Herbal concoctions, Gambaru - Ngala, Public, Schistosomosis

\section{Introduction}

Haemoparasitosis is endemic in tropical and subtropicalCountries, with Schistosomosis seconded by
Malaria are most common and very important childhood diseases in Nigeria where sources of infection occur [5, 14]. Human Schistosomosis or bilharzias, a parasitic infection by Schistosoma haematobium [4, 21], known as "Wuar" in 
Kanuri, "Tsegiya" in Hausa, and "Bolhar" in Shuwa Arab languagesrespectively, is signified by the presence of blood in urine, or haematuria or known as urinary or vesical Schistosomo sis or blood in faeces $[14,22]$. The disease Schistosomosis or Bilharzias in honour of the discoverer, Theodore Bilharz,(1851) in Egypt, covers a group of disease caused by a certain digenetic blood fluke, of the family Schistosomatidae and genus Schistosoma, [2, 4, 8, 11, 24, 29].

Recently, the World Health Organization (WHO) estimated that 200 million people have Schistosomosis worldwide, with over 600 million people at risk of infection which is usually acquired by children aged 15 to 20 years old [11]. The disease is a major source of morbidity and mortality in developing countries, especially Africa where it represents one of the seven (7) tropical diseases [1, 2] with socio economic and public health importance [9, 30]. An estimated 200million people in seventy four (74) countries are infected with the disease, with about 100 millions in Africa as reporter by World Health Organization (WHO). Nigeria is reported as the endemic country in Africa $[5,17$, 24].Schistosomes have a typical trematode vertebrate and invertebrate life cycle, man being the definitive host while aquatic snail is the Intermediate host depending on the species. The life cycle is common to all species with sexual generation in the vascular system of the definitive host and an asexual generation in the intermediate host. Parasite eggs (ova) are released (from the mature copulated Worms) into the environment by infected individuals (urine or faeces of definitive host), rupturing in contact with water, hatch to release the free swimming Miracidium. The ciliated Miracidium infect fresh water snails by penetrating the snail's foot, then developing to Sporocysts which in about four weeks, divide by mitosis in to thousands of new parasite called Cercaria which are the infective larvae or Worms $[1,2,3,8,17,20]$. The inter mediate host of Schistosomes are 3 genera fresh water snails. The Miracidia of S.haematobium find sand penetrate snail's tissues of the genus Bulinus species, while that of $S$. mansoni and $S$. japonicum penetrate Biomphalaria and Oncomelaria tissue respectively [10,12, 25]. Bulinus specie is widely distributed and in Africa, Madagascar, Western Asia and Southern Europe [15, 18, 20].

The frequency of infection among individuals is based on the geographic distribution of endemic Schistosomosis within the tropical and subtropical regions of Africa, Asia, the Middle East, and the Caribbean. However, all humans appear equally susceptible if exposed to infection $[1,2,26,27]$.

The prevalence and the severity of Schistosomal infection vary with age. Children and adolescents are most often heavily infected. Infections peak in individuals aged 10-19 years and in some are as, the prevalence in this group may reach $100 \%[1,16,17]$.The prevalence of active infection and egg counts slowly decline in populations living in endemic areas and endstage complications may persist or worsen. The decline in active infection may reflect that individual shave an increasing host immune response or decreasing exposure to contaminated water [1,
19, 20, 26, 28]. Humans get infection through skin penetration by the infective Cercaria. The infective larva, or Cercaria, penetrate theunbroken skin to get in to the circulation by using proteolytic enzymes, hence reaches the Venusplexus of the bladder. The copulated parasitic worms mature and begin laying eggs, which are passed down during urination $[1,2,3,8,10,13,19,23]$.

The treatment of Schistosomosis recognises praziquantel (Biltricide) as the drug of choice with a cure rate of equal toor better than $85 \%$. Intensity of infection is reduced in $99 \%$ of patients. Metrifonate works well on S. haematobium, while less expensive Oxamniquine works well on $S$. mansoni and nothing else works very well on S. Japonicum [17]. The disease can be prevented and transmission controlled with a single annual dose of praziquantel [5].Preventive measures include the treatment of cases to reduce egg loadsand the reduction or elimination of the snail intermediate host, the in habitats, sanitation measures, and protective foot wears, availing from swimming in the contaminated or suspected water, ditches, rivers or any swampy areas $[3,4,8,10,17]$.The objective of this survey study is to determine the public awareness of the disease Schistosomosis among the populace of Gomboru - Ngala, Nigeria.

\section{Materials and Method}

\subsection{Study Area and Location}

Ngala Local Government Area is located in Borno state (graticles coverage of longitude $305^{\circ}$ East and latitude $115^{\circ}$ North respectively), North eastern Nigeria [13]. Ngala LGA has graticles coverage of longitude $13^{\circ} 45^{\prime}$ East to $14^{\circ} 45^{\prime}$ East and latitude $11^{\circ} 45^{\prime}$ North to $12^{\circ} 45^{\prime}$ North. It is a densely populated area of 158 persons per square kilometre $\left(158 / \mathrm{km}^{2}\right)$, and has an area of about $1528 \mathrm{Km}^{2}$ and an area land mark of $1500 \mathrm{Km}^{2}$ [13]. It has a total population of 237,071 persons, of which 110,375 are females and 126,696 are males respectively [6]. The climatic conditions are of hot season, with temperature of $36^{\circ} \mathrm{C}$ to $42^{\circ} \mathrm{C}$ recorded between the months of March and April. The vegetation is of Savannah and mixed wood land, moderate rainfall, with an annual of $500 \mathrm{~mm}$ to $600 \mathrm{~mm}[7,9]$.

\subsection{Materials Used}

Compound structured and closed and opened ended questionnaires were used for the purpose of information and data collection on the awareness of the disease Schistosomosis in the study area.

\subsection{Method Used}

Prior to this study, a letter of introduction and request for permission to conduct the research study was conveyed to the Honourable Chairman of Ngala Local Government Area, Borno state, through the Education Secretary, Local Education authority, and as such, permission was granted and issued with a letter of approval. 


\subsubsection{Pilot Survey}

Firstly, pilot survey was conducted in order to test the quality of the questionnaire intems of content and the acceptability by the populace of the communities concerned and involved. Fifty (50) compound structured open and close ended questionnaires were distributed and administered to the respondents, and Forty eight (48), out of the said number administered were retrieved. This revealed that, the questionnaires issued were found to be in order and does not mitigate any ethics of the tradition of the people of the targeted area of the research study.

\subsubsection{Distribution of Questionnaire}

The compound structured closed and open ended questionnaires produced for the purpose of this research study were administered to some individuals' members of the communities within the study area randomly. One thousand and twenty $(1,020)$ sets of questionnaires were distributed for the purpose of collecting information and data on the awareness of the disease Schistosomosis. Out of this number, only one thousand $(1,000)$ filled in questionnaires were retrieved successfully. The data obtained in this study were kept highly confidential for further subjection to statistical analyses.

\subsection{Data Analyses}

The data obtained in this study were subjected to statistical tools of analysis by using Chi square $\left(\mathrm{X}^{2}{ }_{0.05 \text { level of }}\right.$ significance), Percentage, Total, Mean, and Standard Deviation to test for the degree of variations among set of means as described by Steel and Torrie, (1990).

\section{Results and Discussion}

\subsection{Results}

The survey on the awareness on the Schistosomosis infection in Ngala LGA, was conducted for the purpose of acquiring information on the public awareness of the disease Bilharzia or Schistosomosis, among the populace of the communities interviewed. One thousand (1000) respondent s were involved, among this number, 572 (57\%) are males, while $428(43 \%)$ were found to be females which was reflected in the Table1.

The results shown in Table1; according to their agegroup distribution, those respondents under the age-group of less than 8 years (yrs) old are 33 with 19 males and 14 females were involved. Those within the age-group of 9 to $18 \mathrm{yrs}$ are 228 having 123 males and 105 females which having the highest number of respondents involved in the study. Those under the age group of 19 to 28 yrs are 220 with 119 males and 101 females. Within the age-group of 29 to 38 yrs old are 215 with 117 males and 98 females, while those at the age group of 39 to 48 yrs are 195 with 108 males and 87 females. Those at the age group distribution of 49 to $58 \mathrm{yrs}$ old are 79 in number with 64 males and 15 females. Lastly, those within the age group of59 to 68 are 30 with 22 males and 8 females which were having the least number of respondents involved in the Study respectively.

Table2 shows the educational background of the respondents interviewed in this study based on their age group distribution. Those that attended primary school are $74(7 \%)$ and the highest among this number are those within the age group of 9 to 18 years old with 21 . Those falls within less than 8 years are 9 in number. Those within the age group of59 to 68 are the least with 1 person only and followed by those within the age group of 39 to 48 years having 5 respondents, and then 49 to 58 years are with 6 , and 29 to 38 yrs are 8 only. Those said they had attended secondary school are $280(28 \%)$ and the highest age group are those within 9 to 18 yrs with 99 respondents, and then followed by 19 to 28 yrs with 72 and 29 to 38 yrs are 35 . The least are those within the age group less than 8 yrs with none, followed by59 to 68 yrs with 23,49 to 58 yrs are 25 and 39 to 48 yrs having 26 respondents.

Those that under gone tertiary educations are 149 (15\%), among this, age group of 9 to 18 yrs are the highest with 9 respondents. Those within 19 to 28 yrs are 72 and 29 to 38 yrs are having 35 respondents. The least in this age group of less than $8 \mathrm{yrs}$ are none, and 59 to $68 \mathrm{yrs}$ are 23, 49 to 58 yrs are 25 and then 39 to 48 are with 26 respondents.

In another observation made, those that said they acquired Arabic education are 434 (34\%) respondents. Among this number, the highest are those within the age group 9 to 18 yrs are 167,19 to 28 yrs are 97 and 29 to 38 yrs are 56.Themoderate in numbers are those within the age group of 59 to $68 \mathrm{yrs} 40$ respondents. The least in this category are the age group of 39 to 48 yrs with 22, followed by less than 8 yrs are 24 and the 49 to 58 yrs are 28 respondents.

Next, are those respondents that said they attended other skill acquisition as their educational backgrounds are 63 $(6 \%)$. The highest among this numbers are 39 to $48 \mathrm{yrs}$ and 59 to 68 yrs old with 13 each, followed by 29 to 38 yrs with 11 and then 9 to $18 \mathrm{yrs}$ are having 10 respondents. The least are those within the age group of less than 8 yrs with no thing and then 49 to 58 yrs are 7 , those within 19 to 28 yrs with 9 respondents.

In another observation made from Table3, it shows that, the age group distribution of the respondents based on their occupations. Those that claimed to be farmers were 349 (35\%), the highest age group are those within 59 to $68 \mathrm{yrs}$ old with 109 and then followed by 49 to 58 yrs with 82 in number, 39 to 48 yrs with 51 respondents and 29 to 38 yrs old with 47 . The least are those within the age to group of less than 8 yrs with no any respondent involved, then 9 to 18 yrs with 21 and followed by 19 to 28 yrs with 21 respondents respectively.

Those that said they are students were found to be 235 $(24 \%)$ out of the total numbers of respondents interviewed. Among this number, 19 to 28 yrs old are the highest with 89 respondents, then 29 to 38 yrs with 61 and followed by 9 to 18 yrs with 54 . The moderate are within 39 to 48 yrs 
with 29, while the least are those within the age group of 49 to 58 yrs with 2 respondents and then, less than 8 yrs and 59 to 68 yrs old were having no respondents.

In the same table, it shows that some of the respondents that said they are Civil Servants were 125 (13\%) and the highest among this number are those within the age group of 39 to 48 yrs are with 46 and 29 to 38 yrs old are with 31,49 to 58 yrs are with 27 respondents. The moderate in this group are those with in 19 to 28 yrs with 17 , the least are those within less than 8 yrs with no any respondent and those within 9 to $18 \mathrm{yrs}$ and 59 to 68 yrs are having 2 respondents each respectively.

With regard to the types of the respondents occupation, Businessmen are not left behind in this table, it shows that 291 (29\%) of the respondents interviewed said that they are Businessmen. Those at the age group of 29 to $38 \mathrm{yrs}$ are the highest with 69 respondents, followed by 39 to 48 yrs with61, and then 59 to 68 yrs are with 60 respondents. The moderate in number are those within 19 to 28 yrs are with 48 and the least are those within less than 8 yrs old with no respondent, 39 to $48 \mathrm{yrs}$ old are with 31 and then 9 to 18 yrs are with 22 respondents involved in the research studied.

In another finding, table 4 showed the types of farming practiced by the respondents that claimed to be farmers which were $35 \%$ out of the total percentage. Among this, those that are practicing fishing were $79(8 \%)$, and the highest are those within the age group of 29 to 38 yrs old with 23respondents, then 19 to 28 yrs have 20 and then followed by 9 to 18 yrs with 14 respondents. Moderately, are those within the 39 to 48 yrs with 11 and the least are those within the age group of less than 8 yrs with none, then 59 to68 yrs with 4 and 49 to 58 yrs with 7 respondents were involved.

Those that they are practicing Irrigation as means of farming were $62(6 \%)$, The highest number of respondents are those within 49 to $58 \mathrm{yrs}$ with 19 , then 29 to $38 \mathrm{yrs}$ with14, 29 to 38 yrs with 14 , then 39 to 48 yrs with 12 and the moderate in number of respondents are 19 to $28 \mathrm{yrs}$ have 10 , while the least are less than 8 yrs with none and followed by 59 to 68 yrs old with 3 and 9 to 18 yrs old with 4 respondents.

In the same table, it also shows that those practicing Fadama farming are $69(7 \%)$. The highest are those with 29 to 38 yrs with 21,39 to 48 yrs with 19 and 9 to 18 yrs old with 13 respondents. While the least are those within less than 8 yrs with none, 59 to 68 yrs with 4, and then 19 28 yrs and 49 to 58 yrs old were having 6 respondents each respectively.

In the table, it showed those respondents interviewed that said they are Rice farmers were $71(7 \%)$. The highest among the age group are 29 to 38 yrs old with 21,39 to 48 yrs with 18 and 19 to 28 yrs old with 14 respondents. The moderate in number of respondents are those within 9 to 18 yrs with 12 and the least are those within less than 8 yrs with none, 59 to 68 yrs have 1 and then 49 to 58 yrs have 5 respondents involved in the research studied.

Those that said they are Wheat -farmers are 68 (8\%), out of those who claimed to be farmers as their occupation. The highest among this, are those within the age group of 29 to 38 yrs have 17,19 to $28 \mathrm{yrs}$ and 49 to $58 \mathrm{yrs}$ old are having 13 respondents each, while the least are those within the age group of less than 8 yrs with none, 9 to $18 \mathrm{yrs}$ and 59 to 68 yrs old are having 7 respondents each and 39 to 48 yrs are with 11 respondents respectively.

Table 5 shows the sources of water for domestic activities of the respondents interviewed in this research studied according to age group distribution. The respondents that said ponds are their source of water for daily domestic activities were 128 (23\%). Within the age group of 29 to 38 yrs old have 25 respondents which is the highest, 19 to 28 yrs are with 24 , then 49 to 58 yrs are 23,9 to $18 \mathrm{yrs}$ are with 22 respondents. While the least are those within the age group of 59 to $68 \mathrm{yrs}$ with 6 , less than $8 \mathrm{yr}$ shave 8 , and then 39 to 48 yrs are with 20 respondents respectively.

Those that said Ditches are their source of water for their domestic activities are $152(15 \%)$ respondents. The highest among these are those age group of 29 to 38 yrs old with 31 , then 9 to 18 yrs are 29,59 to 68 yrs 24 and then 19 to 28 yrs and 39 to 48 yrs are having 23 respondents each. While the least are those within the age group of less than 8 yrs are with 3 and 49 to 58 yrs old are 19 respondents involved in the study.

Also in the same table, the respondents that said Rivers are their source of water for their domestic activities were $147(15 \%)$. Out of this numbers, the highest among these populations are those within the age group of 9 to $18 \mathrm{yrs}$ have 34 and 19 to 28 yrs old have 27,29 to 38 yrs old have 23 and 49 to 58 yrs 21 respondents. While the least are those within less than 8 yrs are 5 , then 59 to 68 yrs are 18 and then 39 to 48 yrs are with 19 respondents involved.

Those respondents that said Pipe Bore Holes are their source of water for their activities were 351 (35\%). Out of these, the highest are those within 19 to 28 yrs with 73,39 to 48 yrs have 71,49 to 58 yrs have 57 and then 29 to 38 yrs are 52 respondents. While the least are those within the age group 59 to 68 yrs old with 23 , less than 8 yrs have 28 and 9 to $18 \mathrm{yrs}$ old have 47 respondents in the research respectively.

The respondents that said Swampy water is their source of water for their daily domestic activities were $222(22 \%)$ involved. Among this, the highest are those within the age group of 59 to $68 \mathrm{yrs}$ with 45 , then followed by 29 to 38 yrs old with 39, and then 39 to 48 yrs are with 36 and then 9 to 18 yrs old 32 respondents. The least are those within age group of less than 8 yrs with 15, and then 19 to 28 yrs old with 26 and 49 to 58 yrs old with 29 respondents were involved in this research studied.

Table 6 shows the responses given by the respondents interviewed on the awareness of the disease bilharzias or Schistosomosis. Out of the total respondents, 4347 (62\%) responded with answered yes (positive answers) while 2653 (38\%) responded with answered no (negative answers). Seven item questions were enquired in this 
studied research from the respondents involved.

That is, out of the 1000 respondents interviewed on the awareness of the disease bilharzias, only $463(46 \%)$ said that they are aware of the disease. $705(71 \%)$ of the respondents said that they have been once infected with the disease bilharzias. On the commonness of the disease in the studied area, 826 (83\%) of the respondents said the disease was common in the area. When interviewed on whether been experienced the presence of blood in urine when urination, $741(74 \%)$ of the respondents said that, they have been experienced. 431 (43\%) of the respondents said that, their urine had been tested in the laboratory before obtaining treatment of the disease bilharzias. Some of the respondents interviewed, $802(80 \%)$ said that, water snails are in abundance in their area and lastly are those respondents, $379(38 \%)$ that said, they are aware of the fact that water snails transmits disease causing organisms, that is, infective worms.

Table 7 showed where treatment are being obtained by the respondents which were $705(71 \%)$, and said that they were ever been infected with the disease bilharzias. Among the respondents that said they obtained treatment from Chemist are 101 (10\%); the highest of this, based on their age groups are 9 to 18 yrs with 26, 29 to 38 yrs have 24,19 to 28 yrs have 21 and then 39 to 48 yrs have 14 respondents The moderate in number of respondents are those within the age group of 49 to 58 yrs old with 7 , while the least are within 59 to 68 yrs old have 4 and less than 8 yrs old have 5 respondents.

The table also showed those respondents that used to obtained treatment from Dispensary were 124 (12\%); the highest among them are those within 9 to 18 yrs old with 23,39 to 48 yrs old with 21, 59 to 68 yrs old have 20, and then 49 to 58 yrs have 19 respondents. Moderate among these number are those within 29 to 38 yrs have 18 and the least are those within less than 8 yrs with 11 and 19 to 28 yrs have 12 respondents involved.

Those that obtained treatments from Clinic were found to be 139 (14\%); the highest among the s numbers are those within the age group of 9 to 18 yrs old with 31,19 to 28 yrs have 27, 39 to 48 yrs old have 25, and 59 to 68 yrs have 19 respondents. The least are those within less than 8 yrs old with 6,29 to 38 yrs old have 14 and then 49 to 58 yrs old have 17 respondents respectively.

Also within the same table, it showed the treatment been obtained from Comprehensive Health Centre by the respondents $61(6 \%)$ interviewed; the highest are those within age group of 29 to 38 yrs old have 19 respondents, 19 to 28 yrs old have 16,39 to 48 yrs old have 11 and 49 to 58 yrs have 9 respondents. While the least are those within less than 8 yrs and 59 to 68 yrs old have 1 respondent each and then 9 to 18 yrs old have 4 respondents involved in the research studied.

In another observation, table 8 shows the type of traditional methods of treatment used by the respondents interviewed for treating bilharzias (Schistosomosis) which were found to be 241 (24\%); Among this number, those respondents (based on their age group) that said they used baked broken pots soaked in water for drinking as traditional methods of treatment are $54(5 \%)$ and the highest are within 9 to 18 yrs old are with 17,19 to 28 yrs old have 13, 29 to 38 yrs old have 9,49 to 58 yrs old and 59 to 68 yrs each have 5 respondents. The least are that within less than 8 yrs have 1 and 39 to 48 yrs old have 4 respondents respectively.

In the same table, it showed that, those respondents that said they used spiritual incarnation as means of traditional treatment of the disease Schistosomosis were 80 (8\%); The highest are 39 to $48 \mathrm{yrs}$ old have 18,59 to $68 \mathrm{yrs}$ old have 16,9 to 18 yrs have 13 and then 29 to 38 yrs have 12 respondents. The least are those within less than 8 yrs old are with 2, 19 to 28 yrs old have 9 and 49 to 58 yrs old have 10respondents,

Among the respondents that said they used Herbal concoctions as means of traditional methods of treatment of bilharzias (Schistosomosis) were $47(5 \%)$; The highest of this number are those that are within the age group of 19 to 28 yrs old have 12,9 to 18 yrs old have 11,29 to 38 yrs old and 49 to 58 yrs old have 5 respondents each, while the least are those at the age group of less than 8 yrs old have none and 39 to 48 yrs old have 3 respondents involved.

The table also showed the results of the research studied, those respondents that said they used sour milk whey as means of traditional medicine for the treatment of bilharzia (Schistosomosis) were found to be $60(6 \%)$; and out of this number, the highest are those within the age group of 19 to $28 \mathrm{yrs}$ old are with 16, 59 to $68 \mathrm{yrs}$ are 13 in number, 49 to 58 yrs old are 8,39 to 48 yrs old, 29 to 38 yrs old and 9 to 18 yrs old have 7 respondents each, while the least are those within the age group of less than 8 yrs with 2 respondents involved respectively.

In table 9, it shows the responses of the respondents interviewed according to their age group distribution on the common major sign and symptoms of the disease bilharzias (Schistosomosis); Out of the total respondents interviewed, $476(48 \%)$ were found to said that the presence of blood in urine is the common major sign and symptoms of the disease bilharzias and the highest among these groups are those within the age group of 29 to 38 yrs old with 149,39 to 48 yrs old have 96,19 to 28 yrs old have 93,49 to 58 yrs old have 57 and then 9 to 18 yrs old have 45 respondents. The least are that within less than 8 yrs old have none and 59 to 68 yrs old have 42 respondents respectively.

Another findings within the same table which revealed that, the respondents that said the common major sign and symptoms of the disease bilharzias is that the presence of blood in faeces were found to be 291 (29\%); the highest among this number are those within 29 to 38 yrs old have 62,59 to 68 yrs old have 51,39 to 48 yrs old have 49,19 to 28 yrs old have 45 and then 49 to 58 yrs old have 43 respondents. The least are that within the age group of less than 8yrs old with none and 9 to 18 yrs old have 41 respondents involved.

The same table reveals the result of those respondents 
that said that, painful urination is the common major sign and symptoms of the disease bilharzias were $144(15 \%)$; the highest age group among this group are those within 29 to 38 yrs old with 41,49 to 58 yrs old have 36,39 to 48 yrs old have 28 and then 59 to 68 yrs old have 27 respondents. The least are those within the age to group of less than 8 yrs old have none, 19 to 28 yrs old have 8 and 9 to 18 yrs old 4 respondents involved in studied.

Within the same table, the results revealed that, those respondents interviewed said that emaciation is the common major sign and symptoms of the disease bilharzias were found to be $83(8 \%)$; The highest among them and according to their age group are those respondents within 49 to 58 yrs old have 27,39 to 48 yrs old have 20,59 to 68 yrs old have 16 and then 29 to 38 yrs old have 15 respondents, while the least are those age group within less than 8 yrs old none, 9 to 18 yrs old have 3 and then 19 to 28 yrs old have 2 respondents respectively.

The finding of the research studied, in table 10 revealed that, the responses of the respondents interviewed on the ways of contact with the disease bilharzias within the study area are as follows; those that said that, the way of contact with the disease bilharzias is from parents to offspring are $47(5 \%)$ of the respondents and the highest among them are those within the age group of 49 to 58 yrs old which have 12,29 to $38 \mathrm{yrs}$ old have 9,59 to $68 \mathrm{yrs}$ old have 8 and then 39 to 48 yrs old have 7 respondents. While the least are those within less than 8 yrs old have none, 9 to 18 yrs old have 2 and 19 to 28 yrs old have 4 respondents respectively.

Within the same table, the results showed that those respondents that said, it is through sexual intercourse are 107(11\%); the highest age group are those within 39 to 48 yrs old have 32,19 to 28 yrs old have 21,29 to 38 yrs have 19 and 59 to 68 yrs old have 16 respondents. The least are those within less than 8 yrs old have none, 49 to 58 yrs old have 16 and 9 to 18 yrs old have 10 respondents involved in the study.

Another observation made from the same table was on those respondents that said, it is through swimming that one's get in contact with the disease (Schistosomosis) are $306(31 \%)$; the highest among this number are that with in
59 to 68 yrs old have 59,49 to 58 yrs old have 58, 29 to 38 yrs old have 51 and 39 to 48 yrs old have 49 respondents involved. The least were found to be those within the age group of less than 8 yrs old have none, 9 to $18 \mathrm{yrs}$ old have42 and then 19 to 28 yrs old have 21 respondents.

Within the same table, it was observed that those respondents that said the ways of in contact with the disease bilharzias is through in contact with contaminated waters were found to be 167 (17\%); the highest among this group of respondents are those within 49 to 58 yrs old have 45,59 to 68 yrs old have 29,29 to 38 yrs old have 27 and then 9 to 18 yrs old have 26 respondents, while, the least are those within less than 8 yrs old have none, 19 to $28 \mathrm{yrs}$ old have 22 and finally those within 9 to 18 yrs old have 26 respondents involved.

The same table revealed that those respondents that said the ways of contact with the disease bilharzias is through drinking and eating food were found to be 259 (26\%); the highest of this group are those with in 9 to 18 yrs old which have 67 , followed by 18 to 28 yrs old have 48,49 to 58 yrs old have 43 and then 39 to 48 yrs old have 40 respondents. The least are those within the age group are those within less than 8 yrs old have none, 29 to 38 yrs old have 19 and59 to 68 yrs old have 35 respondents respectively.

The table also revealed that, those respondents that said the ways of contact with the disease bilharzias is through inhaling were found to be 63 (6\%); out of this number, the highest are those respondents within 39 to 48 yrs old have 20, 29 to 38 yrs old have 19, 49 to 58 yrs old have 18 and 59 to 68 yrs old have 5 respondents respectively, and least are those within the age group of less than 8 yrs old have and 9 to 18 yrs old have none each and then 19 to 28 yrs old have 1 respondents involved.

From the same table, it revealed that, those respondents interviewed that said it is through Irrigation that one's get in contact with the disease bilharzias were $56(6 \%)$; the highest among the group are those within the age group of 59 to 68 yrs old have 18,49 to 58 yrs old have 13, 29 to 38 yrs old have 10 and 39 to 48 yrs old have 7 respondents, while the least are those within less than 8 yrs old have none, 19 to 28 yrs old have 3 and then 9 to 18 yrs have 5 respondents involved in the research studied respectively.

Table 1. Shows the age group distribution of the respondents interviewed.

\begin{tabular}{llll}
\hline \multirow{2}{*}{ Age - group (years). } & \multicolumn{2}{l}{ Sex of the respondents. } & Total. \\
\cline { 2 - 4 } & Males. & Females. & 33 \\
\hline$<8$ & 19 & 14 & 228 \\
$9-18$ & 123 & 105 & 220 \\
$19-28$ & 119 & 101 & 215 \\
$29-38$ & 117 & 98 & 195 \\
$39-48$ & 108 & 87 & 79 \\
$49-58$ & 64 & 15 & 30 \\
$59-68$ & 22 & 8 & 100.0 \\
Percentage: & 57.2 & 42.8 & $1000(142.9 \pm 91.3)$. \\
Total (Mean \pm ST Dev.). & $572(81.7 \pm 46.3)$. & $428(61.1 \pm 46.0)$. & \\
\hline
\end{tabular}


Summary of Table 1 Analysis:

$H_{1}$ : that there is a relationship between the sexes of the respondents interviewed in Ngala Local Government, Borno State, Nigeria.

$H_{o}$; that there is no relationship between the sexes of the respondents interviewed in Ngala Local Government, Borno State, Nigeria.

Variable. Percentage. Total. Mean. Standard Deviation Critical Calculated Degree of freedom Results.

Males 57.257281 .7 46.312.592 509.8 6 The critical value is highly

Females 42.842861 .1 16.0 less than the calculated value.

Hence, $\mathrm{H}_{1}$ is rejected and $\mathrm{H}_{0}$ is accepted. i.e.,
There is no any relationship between the sexes of the respondents in the community that the research studied.

Level of significance is equal to 0.05 (critical level).

\section{Comments:}

That, $\mathrm{H}_{\mathrm{o}}$ stated that, there is no any relationship between the sexes of the respondents interviewed in the research studied at Ngala Local Government Area of Borno state, Nigeria. Therefore, $\mathrm{H}_{0}$ is accepted. That, $\mathrm{H}_{0}$ stated that, there is no any relationship between the sexes of the respondents interviewed in the research studied at Ngala Local Government Area of Borno State, Nigeria. Therefore, $\mathrm{H}_{0}$ is accepted

Table 2. Shows the educational background of the respondents interviewed.

\begin{tabular}{|c|c|c|c|c|c|c|c|}
\hline \multirow{2}{*}{$\begin{array}{l}\text { Serial } \\
\text { number. }\end{array}$} & \multirow{2}{*}{$\begin{array}{l}\text { Age - group. } \\
\text { (years). }\end{array}$} & \multicolumn{5}{|c|}{ Educational status. } & \multirow{2}{*}{ Total } \\
\hline & & Primary. & Secondary. & Tertiary. & Arabic. & Other skills & \\
\hline 1. & $<-8$ & 9 & 0 & 0 & 24 & 0 & 33 \\
\hline 2. & $9-18$ & 24 & 99 & 5 & 167 & 10 & 305 \\
\hline 3. & $19-28$ & 21 & 72 & 58 & 97 & 9 & 257 \\
\hline 4. & $29-38$ & 8 & 35 & 33 & 56 & 11 & 143 \\
\hline 5. & $39-48$ & 5 & 26 & 15 & 22 & 13 & 81 \\
\hline 6. & $49-58$ & 6 & 25 & 17 & 28 & 7 & 83 \\
\hline 7. & $59-68$ & 1 & 23 & 21 & 40 & 13 & 98 \\
\hline \multicolumn{2}{|c|}{ Percentage: } & 7.4 & 28.0 & 14.9 & 43.4 & 6.3 & 100.0 \\
\hline \multicolumn{2}{|c|}{ Total (Mean \pm ST Dev.). } & $74(10.6 \pm 8.6)$ & $280(40.0 \pm 33.8)$ & $149(21.3 \pm 19.4)$ & $434(62.0 \pm 53.1)$ & $63(9.0 \pm 4.5)$ & $1000(142.9 \pm 100.7)$ \\
\hline
\end{tabular}

Table 3. Shows the occupations of the respondents based on their age-group distribution.

\begin{tabular}{|c|c|c|c|c|c|c|}
\hline \multirow{2}{*}{$\begin{array}{l}\text { Serial } \\
\text { Number. }\end{array}$} & \multirow{2}{*}{$\begin{array}{l}\text { Age - group. } \\
\text { (years). }\end{array}$} & \multicolumn{4}{|c|}{ Types of occupation. } & \multirow{2}{*}{ Total } \\
\hline & & Farmers. & Students. & Civil servants. & Businessmen. & \\
\hline 1. & $<-8$ & 0 & 0 & 0 & 0 & 0 \\
\hline 2. & $9-18$ & 21 & 54 & 4 & 22 & 101 \\
\hline 3. & $19-28$ & 39 & 69 & 17 & 48 & 173 \\
\hline 4. & $29-38$ & 47 & 61 & 31 & 69 & 208 \\
\hline 5. & $39-48$ & 51 & 29 & 38 & 61 & 179 \\
\hline 6. & $49-58$ & 82 & 12 & 27 & 31 & 152 \\
\hline 7. & $59-68$ & 109 & 10 & 8 & 60 & 187 \\
\hline \multicolumn{2}{|c|}{ Percentage: } & 34.9 & 23.5 & 12.5 & 29.1 & 100.0 \\
\hline \multicolumn{2}{|c|}{ Total (Mean \pm ST Dev.): } & $349(49.9 \pm 36.5)$ & $235(33.6 \pm 28.0)$. & $125(17.9 \pm 14.6)$ & $291(41.6 \pm 24.9)$ & $1000(142.9 \pm 71.4)$. \\
\hline
\end{tabular}

Table 4. Shows the types of farming practiced by the respondents that claimed to be farmers according to their age - group distribution.

\begin{tabular}{|c|c|c|c|c|c|c|c|}
\hline \multirow{2}{*}{$\begin{array}{l}\text { Serial } \\
\text { Number. }\end{array}$} & \multirow{2}{*}{$\begin{array}{l}\text { Age - group. } \\
\text { (years). }\end{array}$} & \multicolumn{5}{|c|}{ Types of farming been practiced. } & \multirow{2}{*}{ Total. } \\
\hline & & Fishing. & Fadama. & Irrigation. & Rice - farming. & Wheat - farming. & \\
\hline 1. & $<-8$ & 0 & 0 & 0 & 0 & 0 & 0 \\
\hline 2. & $9-18$ & 14 & 13 & 4 & 12 & 7 & 50 \\
\hline 3. & $19-28$ & 20 & 6 & 10 & 14 & 13 & 63 \\
\hline 4. & $29-38$ & 23 & 21 & 14 & 21 & 17 & 96 \\
\hline 5. & $39-48$ & 11 & 19 & 12 & 18 & 11 & 71 \\
\hline 6. & $49-58$ & 7 & 6 & 19 & 5 & 13 & 50 \\
\hline 7. & $59-68$ & 4 & 4 & 3 & & 7 & 19 \\
\hline \multicolumn{2}{|c|}{ Percentage: } & 22.6 & 19.8 & 17.8 & 20.3 & 19.5 & 100.0 \\
\hline \multicolumn{2}{|c|}{ Total (Mean \pm ST Dev.). } & $79(11.3 \pm 8.4)$ & $69(9.9 \pm 7.9)$ & $62(8.9 \pm 6.8)$ & $71(10.1 \pm 8.3)$ & $68(9.7 \pm 5.6)$ & $349(49.9 \pm 32.1)$. \\
\hline
\end{tabular}


Table 5. Shows the source of water for domestic activities of the respondents interviewed.

\begin{tabular}{llllllll}
\hline $\begin{array}{l}\text { Serial } \\
\text { Number. }\end{array}$ & $\begin{array}{l}\text { Age }- \text { group. } \\
\text { (years). }\end{array}$ & \multicolumn{2}{l}{ Source of water for domestic activities. } \\
\cline { 2 - 7 } & Ponds. & Ditches. & Rivers. & Electric bore holes. & Swampy. & Total. \\
\hline 1. & $<-8$ & 8 & 3 & 5 & 28 & 15 & 59 \\
2. & $9-18$ & 22 & 29 & 34 & 47 & 32 & 164 \\
3. & $19-28$ & 24 & 23 & 27 & 73 & 26 & 173 \\
4. & $29-38$ & 25 & 31 & 23 & 52 & 39 & 170 \\
5. & $39-48$ & 20 & 23 & 19 & 71 & 36 & 169 \\
6. & $49-58$ & 23 & 19 & 21 & 57 & 29 & 149 \\
7. & $59-68$ & 6 & 24 & 18 & 23 & 45 & 116 \\
PERCENTAGE & 12.8 & 15.2 & 14.7 & 35.1 & 22.2 & 100.0 \\
TOTAL (Mean \pm ST Dev.) & $128(18.3 \pm 7.2)$. & $152(21.7 \pm 9.2)$. & $147(21 \pm 8.9)$. & $351(50.1 \pm 19.3)$. & $222(31.7 \pm 9.7)$. & $1000(142.9 \pm 42)$. \\
\hline
\end{tabular}

Table 6.Shows the responses given by the respondents interviewed on the awareness of disease bilharzias.

\begin{tabular}{lllll}
\hline Serial items questioned. & \multicolumn{2}{l}{ Responses given. } & Percentage. \\
\hline Number. & Yes. & Percentage. & No. & 53.7 \\
\hline 1.Are you aware of the disease Bilharzias? & 463 & 46.3 & 537 & 29.5 \\
2.Have you ever been infected with the Disease Bilharzias? & 705 & 70.5 & 295 & 17.4 \\
3.The disease Bilharzias, it's common in your area? & 826 & 82.6 & 174 & 25.9 \\
$\begin{array}{l}\text { 4.When passing urine, have you ever been experienced the presence } \\
\text { of blood in your urine? }\end{array}$ & 741 & 74.1 & 259 & 56.9 \\
5Before treatment, have your urine been tested in the Laboratory & 431 & 43.1 & 569 & 19.8 \\
(Diagnosed)? & 802 & 80.2 & 198 & 62.1 \\
6.Are water Snails in abundance in your area? & 379 & 37.9 & 621 & 37.9 \\
7.Are you aware that water Snails transmits Diseases causing & & & $2653(379 \pm 189.7)$. \\
Organisms (Worms)? & 62.1 & $4347(621 \pm 189.7)$. & \\
PERCENTAGE: & & & \\
TOTAL (Mean \pm ST Dev.). & & & \\
\hline
\end{tabular}

Summary of Table 6 Analyses:

$H_{1}$ : that the populace of the community of Ngala Local Government Area, Borno State, Nigeria, are aware of the disease bilharzias.

$H_{o}$; that the populace of the community of Ngala Local Government Area, Borno State, Nigeria, are not aware of the disease bilharzias.

Variable. Percentage. Total. Mean. Standard critical calculated degree results. Deviation value. Value of freedom.

Positive (yes) $62.14347621 .0189 .712 .592 \quad 1657.316$ The critical value is highly
Negative (no) $37.92653379 .0 \quad 189.7$ less than the calculated value.

Hence, $\mathrm{H}_{1}$ is rejected and $\mathrm{H}_{0}$ is accepted. i.e., the populace of the Ngala Local Government Area community are not aware of the disease Bilharzias which was conducted in the research studied.

Level of significance is equal to 0.05 (critical level).

Comments

That, $\mathrm{H}_{\mathrm{o}}$ stated that, the respondents (populace of the community) interviewed in the research studied at Ngala Local Government Area of Borno State, Nigeria are not aware of the disease bilharzias. Therefore, $\mathrm{H}_{0}$ is accepted.

Table 7. Shows the where treatment being obtained by the respondents that said were ever infected with bilharzias.

\begin{tabular}{|c|c|c|c|c|c|c|c|c|}
\hline \multirow{2}{*}{$\begin{array}{l}\text { Serial } \\
\text { Number. }\end{array}$} & \multirow{2}{*}{$\begin{array}{l}\text { Age - group. } \\
\text { (years). }\end{array}$} & \multicolumn{6}{|c|}{ Where treatment were obtained. } & \multirow{2}{*}{ - Total. } \\
\hline & & a. & b. & c. & d. & e. & f. & \\
\hline 1. & $<-8$ & 5 & 11 & 6 & 1 & 0 & 9 & 32 \\
\hline 2. & $9-18$ & 26 & 23 & 31 & 4 & 3 & 32 & 119 \\
\hline 3. & $19-28$ & 21 & 12 & 27 & 16 & 9 & 28 & 113 \\
\hline 4. & $29-38$ & 24 & 18 & 14 & 19 & 13 & 59 & 147 \\
\hline 5. & $39-48$ & 14 & 21 & 25 & 11 & 4 & 53 & 128 \\
\hline 6. & $49-58$ & 7 & 19 & 17 & 9 & 7 & 27 & 86 \\
\hline 7. & $59-68$ & 4 & 20 & 19 & 1 & 3 & 33 & 80 \\
\hline \multicolumn{2}{|c|}{ PERCENTAGE: } & 14.3 & 17.6 & 19.7 & 8.6 & 5.5 & 34.3 & 100.0 \\
\hline \multicolumn{2}{|c|}{ Total (Mean \pm ST Dev.): } & $101(14.4 \pm 9.3)$ & $124(17.7 \pm 4.5)$ & $139(19.9 \pm 8.5)$ & $61(8.7 \pm 7.1)$ & $39(5.6 \pm 4.4)$. & $241(34.4 \pm 16.8)$ & $705(100 \pm 38,2)$ \\
\hline
\end{tabular}

KEYS: a.Chemist.b.Dispensary.c.Clinic.d.ComprehensiveHealthCentre.e.Hospital.f.Treatedtraditionally. 
Table 8. Shows the types of traditional method of treatment used by the respondents interviewed.

\begin{tabular}{|c|c|c|c|c|c|c|}
\hline \multirow{2}{*}{$\begin{array}{l}\text { Serial } \\
\text { Number. }\end{array}$} & \multirow{2}{*}{$\begin{array}{l}\text { Age - group. } \\
\text { (years). }\end{array}$} & \multicolumn{4}{|c|}{ Types of traditional treatment applied. } & \multirow{2}{*}{ Total. } \\
\hline & & a. & b. & c. & d. & \\
\hline 1. & $<-8$ & 1 & 2 & 0 & 2 & 5 \\
\hline 2. & $9-18$ & 17 & 13 & 11 & 7 & 48 \\
\hline 3. & $19-28$ & 13 & 9 & 12 & 16 & 50 \\
\hline 4. & $29-38$ & 63 & 12 & 5 & 7 & 33 \\
\hline 5. & $39-48$ & 31 & 18 & 3 & 7 & 32 \\
\hline 6. & $49-58$ & 5 & 10 & 5 & 8 & 28 \\
\hline 7. & $59-68$ & 5 & 16 & 11 & 13 & 45 \\
\hline \multicolumn{2}{|c|}{ Percentage: } & 22.4 & 33.2 & 19.5 & 24.9 & 100.0 \\
\hline \multicolumn{2}{|c|}{ Total (Mean \pm ST Dev.): } & $54(7.7 \pm 5.2)$ & $80(11.4 \pm 5.2)$ & $47(6.7 \pm 5.6)$ & $60(8.6 \pm 4.6)$ & $241(34.4 \pm 15.6)$ \\
\hline
\end{tabular}

KEYS:- a.Redhot,bakedbrokenpotimmersedinwateranddrinksthemixture.b.Spiritualincarnation.c.Herbalconcoction.d.Sourmilkwheywithcornflakes.

Table 9. Shows the responses of the respondents interviewed on the common major sign and symptoms of bilharzias.

\begin{tabular}{|c|c|c|c|c|c|c|}
\hline \multirow[b]{2}{*}{$\begin{array}{l}\text { Serial } \\
\text { Number. }\end{array}$} & \multirow[b]{2}{*}{$\begin{array}{l}\text { Age - group. } \\
\text { (years). }\end{array}$} & \multicolumn{4}{|c|}{ Common major sign and symptoms. } & \multirow[b]{2}{*}{ Total } \\
\hline & & Presence of Blood in urine. & $\begin{array}{l}\text { Presence of Blood } \\
\text { in faeces. }\end{array}$ & Painful urination. & Emaciation. & \\
\hline 1. & $<-8$ & 0 & 0 & 0 & 0 & 0 \\
\hline 2. & $9-18$ & 45 & 41 & 4 & 13 & 103 \\
\hline 3. & $19-28$ & 93 & 45 & 8 & 2 & 148 \\
\hline 4. & $29-38$ & 139 & 62 & 41 & 15 & 257 \\
\hline 5. & $39-48$ & 96 & 49 & 28 & 20 & 193 \\
\hline 6. & $49-58$ & 57 & 43 & 36 & 27 & 163 \\
\hline 7. & $59-68$ & 42 & 51 & 27 & 16 & 136 \\
\hline \multicolumn{2}{|c|}{ Percentage: } & 47.2 & 29.1 & 14.4 & 9.3 & 100.0 \\
\hline \multicolumn{2}{|c|}{ Total (Mean \pm ST Dev.). } & $472(67.4 \pm 45.6)$ & $291(41.6 \pm 19.6)$ & $144(20.6 \pm 16.4)$ & $93(13.3 \pm 9.6)$. & $1000(142.9 \pm 79.6)$ \\
\hline
\end{tabular}

Table 10. Shows the responses given by the respondents interviewed on the ways of in contact with the disease bilharzias.

\begin{tabular}{|c|c|c|c|c|c|c|c|c|c|}
\hline \multirow{2}{*}{$\begin{array}{l}\text { Serial } \\
\text { Number. }\end{array}$} & \multirow{2}{*}{$\begin{array}{l}\text { Age - group. } \\
\text { (years). }\end{array}$} & \multicolumn{7}{|c|}{ Ways of in contact with the disease bilharzias. } & \multirow[t]{2}{*}{ Total. } \\
\hline & & a. & b. & c. & d. & e. & f. & G & \\
\hline 1. & $<-8$ & 0 & 0 & 0 & 0 & 0 & 0 & 0 & 0 \\
\hline 2. & $9-18$ & 2 & 10 & 42 & 26 & 67 & 0 & 5 & 152 \\
\hline 3. & $19-28$ & 4 & 21 & 47 & 22 & 48 & 1 & 3 & 146 \\
\hline 4. & $29-38$ & 9 & 19 & 51 & 27 & 26 & 19 & 10 & 161 \\
\hline 5. & $39-48$ & 7 & 32 & 49 & 18 & 40 & 20 & 7 & 173 \\
\hline 6. & $49-58$ & 12 & 9 & 58 & 45 & 43 & 18 & 13 & 198 \\
\hline 7. & $59-68$ & 8 & 16 & 59 & 29 & 35 & 5 & 18 & 170 \\
\hline \multicolumn{2}{|l|}{ Percentage } & 4.7 & 10 & 30.6 & 16.7 & 25.9 & 6.3 & 5.6 & 100.0 \\
\hline \multicolumn{2}{|c|}{ Total (Mean \pm ST Dev.): } & $47(6.7 \pm 4.2)$. & $\begin{array}{l}107(15.3 \pm 10 \text {. } \\
2) .\end{array}$ & $\begin{array}{l}306(43.7 \pm \\
20.1) .\end{array}$ & $\begin{array}{l}167(23.9 \pm 13 . \\
5) .\end{array}$ & $259(37 \pm 20.7)$ & $63(9 \pm 9.5)$ & $56(8 \pm 6.1)$ & $\begin{array}{l}1000(142.9 \\
\pm 65.2)\end{array}$ \\
\hline
\end{tabular}

\section{KEYS:-}

a.Fromparenttooffspring.b.Throughsexualintercourse.c.Throughswimming.d.Throughincontactwithcontaminatedwater.e.Throughdrinkingandeatingfood.f. Throughinhaling.g.Throughirrigation.

\subsection{Discussion}

This research studied within the Ngala Local Government Area on the awareness of the disease bilharzias among the populace of the communities of Ngala and its environs reveals that, out of the 1000 respondents interviewed, $57 \%$ are males and $43 \%$ are found to be females. Statistically, the sexes have no any relationship between the male's and the female's respondents. Those under the age group of 9 to 18 years old are the highest in number according to age groups, and followed by those that are within 19 to 28 years old, 29 to 38 years old, 39 to 48 years old and the least are those at the age group of 59 to 68 years old and then those within less than 8years old and lastly are those within the age group of 49 to 58 years old respectively. Within these age groups are the targeted groups of which the suspected disease Schistosomosis in question and investigation is very prone to, active infection and diminishes stages due to induced acquired immunity. Hence, the prevalence and the severity of Schistosomosis infection vary with age; children and adolescence are most often heavily infected. This statement are supported by some authors, viz; Amy, 2005; Kings, 1999; Farley, 1993; 
they stated that, 'infections peak in individual aged 10 to 19 years old and people at risk infection which is usually acquired by children between 15 to 20 years old.'

The results obtained also reveals that based on their education background, those respondents that claimed to attended Arabic education $44 \%$ are the highest in number, followed by those that attended secondary school $28 \%$, those attended tertiary education $14 \%$, those attended primary education $7 \%$ and lastly the least are those said that they acquired other craft skills $6 \%$ respectively. Hence, it was observed that, if public enlightens is to be delivered to the communities of the studied area on the awareness of the disease Schistosomosis or bilharzias, it would be easier to communicate with the populace of the communities, since their educational background has been known.

Based on the occupational status of the respondents, the results obtained reveals that, those claimed that, they are farmers are $35 \%$ which are the highest in number of respondents, Businessmen are $29 \%$, students are $24 \%$ and the least in number are the Civil Servants which are $12 \%$ respectively. Among these populations, the farmers are the most frequently in contact with water which may be contaminate with the suspected infective worms that causes the disease Schistosomosis. This is because, due to the nature of their work which involved the usage of water.

In another finding of the results obtained, those respondents interviewed that said they are farmers are found to be $35 \%$. Out of this number, $8 \%$ of the respondents fishing is their means of living and been the highest the farmer; Irrigation farming are $6 \%$, those who practice Fadama farming are $7 \%$, also Rice farming are $7 \%$ and finally are those who practice wheat farming are $7 \%$ respectively. Hence, the farmers could be a trisk individual or factors, since their occupation involve the usage of water for watering their farms and as a result of this activities of the farmers may come in contact with contaminated water with the infective parasites which makes them to be prone to infection with the disease Schistosomosis.

The results of the research studied showed that the sources of water for the respondents' daily domestic activities are water from the pipe bore holes $35 \%$ which is the highest, Swampy water $2 \%$, Ditches water $15 \%$, Rivers water $15 \%$ and lastly which is the least are from pond swater $13 \%$ respectively. From this results obtained, it is clearly that, the populace of the communities where the research study had been carried out are lacking healthy table water for drinking and their daily domestic activities. This is because; only $35 \%$ of their source of water from Pipe bore holes which may be safe for drinking and perform domestic activities. The rest of the sources of water may be contaminated and rendered unsafe for drinking for both human and livestock and other domestic activities.

Observation made from the results obtained which revealed that, the populace (respondents interviewed) of the communities where these research studied were not aware of the disease bilharzias or Schistosomosis neither its major signs and symptoms or it causative agent (waters nails) which transmits the disease causing organisms. They are only aware of passing blood in urine which they assume as a sign of puberty, locally belief and the aquatic snails which are in abundance in their areas. They noticed the presence of blood in their urine also, and most of them are not being diagnosed before receiving treatments.

The research findings, also reveals that, those respondents that said they applied traditional methods of treatment when infected with the disease bilharzias (Schistosomosis) were found to be $24 \%$; among this number, those respondents that used Baked broken pots as means of traditional treatment for bilharzias are $5 \%$, Spiritual incarnation are $8 \%$, Herbal concoctions are $5 \%$ and then those who used Sourmilk whey are $6 \%$ respectively. There is the need to find out the types of the herbs used by the respondents in order to ascertain the phytochemicals or the substance contents of the herbs that posses the schitosomacidal effects and the sour milk whey that used as traditional schistosomacidal agent. The question need to be asked or the hypothesis to be ascertained is that, is the sour milk whey medium contains certain chemical such as minerals or amino acids that is responsible for the schitosomacidal effects?

In another observations made, the results revealed that the responses of the respondents interviewed on the common major sign and symptoms of the disease bilharzias(Schistosomosis), the highest in percentage among them were found to be $48 \%$ for those that said the presence of blood in urine is the common major sign and symptoms of the disease bilharzias, followed by $29 \%$ for those who said the common major sign and symptoms is the presence of blood in faeces, but those who said that painful urination is the common major sign and symptoms are $15 \%$ and the least are those who said that emaciation is the common major sign and symptoms are $8 \%$ respectively.

Actually, the common major sign and symptoms of urinary bilharzias (Vesicle Schistosomosis) is the presence of blood in urine which the local populace called Bolh har in Shuwa Arab languages, Wuar in Kanuri language and Tsegiya in Hausa language which signifies the presence of blood in urine, and is belief to be as a sign of puberty within the populace of the communities that where the research was conducted.

The results obtained from this study also revealed that among the respondents interviewed on the ways of in contact with the disease bilharzias are as follows; those respondents that said it is through swimming with $31 \%$ (which is highest), it is through drinking and eating with $26 \%$, it is through in contact with contaminated waters are $17 \%$, (which is the correct ways of in contact with the disease bilharzias), those said that it is through sexual intercourse are $11 \%$, it is through inhalation are $6 \%$, and then those who said it is through irrigation are $6 \%$ and lastly are those respondents that said it is from parent to offspring.

Conclusively, out of the total number (1000) of the respondents interviewed, only $17 \%$ gave the accurate answers on ways of in contact with the disease bilharzias. 
That is, through in contact with contaminated waters. Therefore, from the results obtained, it showed that $83 \%$ of the respondents interviewed were not aware of the disease bilharzias (Schistosomosis) in the communities where this research study was conducted.

\section{Conclusion and Recommendations}

\subsection{Conclusion}

Haemoparasitosis is endemic in the tropical and subtropical developing countries including Nigeria, with Schistosomosis seconded by Malaria are the most commonand very important childhood diseases and where sources of infection occur, especially the Schistosoma haematobium infection which is through in contact with contaminated waters. As a result of this, a research study on the survey of awareness of Schistosomosis infection in Ngala Local Government Area, Borno State, Nigeria, became necessary.

The results of the survey study obtained, revealed that, the respondents interviewed on the awareness of the disease bilharzias (Schistosomosis) were found not to be aware of the disease no either it's ways of contacting the disease bilharzias. Also there is no any relationship between the males and the females respondents interviewed in the studied area. As such, when infected with the disease bilharzias, the respondents said, they sort for traditional methods of treatment by using among common are herbal concoctions and sour milk whey as means of treatment of the disease bilharzias, which means only least are promising clinic and hospital for the proper treatment of the disease bilharzias (Schistosomosis).

\subsection{Recommendations}

Authority concern should enlighten the populace of the communities studied on the awareness of the disease bilharzias (Schistosomosis), its ways of infection, proper diagnoses, treatment and prevention.

There is the need to carry out a research study on the types of the herbs used by the populace of the communities as a traditional ways of treating the disease bilharzias, the phytochemical or the medicinal importance of the chemical matter of the herbs used and its folkloric believes, in the studied area, in order to support the folklores on the traditions of the communities involved in the study.

A similar and broad research study is recommended to be carrying out within the same populace of the communities of Ngala Local Government Area, Borno State, Nigeria, on the awareness of the disease bilharzias (Schistosomosis) in order to investigate more and obtain more findings.

\section{Acknowledgement}

We acknowledged the contributions of all those who helped in one way or the other in making this piece of work a success to an end. Our great profound gratitude goes to the
Ngala Local Government Authority, Borno State, Nigeria.

\section{References}

[1] Akinboye, D. O., Ajisebutu, J. U., Fawole, O., Agbolade, O. M., Akinboye, O. M., Amosu, A. M., Atulomah, N. O. S., Awodele, O., Oduola, O.,Owodunni, B.M., Rebecca, S. N., Falade, M. Enem, O. "Urinary Schistosomiasis, Water Contact Frequency and Infectivity among Secondary School Students in Ibadan, Nigeria" Journal of Parasitology, 32 (1); $129-134.2011$

[2] Amy, J and Behrman, M. D.“An article on Schistosomiasis,"E medicine Schistosomiasis, 2005. File:///E:/Abor/emedicine $\% 2$ $\% 20$ Schistosomiasis $\% 20 \% 20$ article $\%$.

[3] Bala, A.Y., Ladan, M.U, and Mainasara, M 'Prevalence and Intensity of Urinary Schistosomiasis in Abarma Village, Gusau, Nigeria:' A Preliminary Investigation. Science World Journal, Vol. 7 Number 2; 2012. WWW.Sciencejournal.org

[4] Betterton, C and Friger, S.E. "A report on a survey on Chad Basin Irrigation".In: Epidemiological Report, Epidemiology Unit, Ministry of Health, Maiduguri, Borno. An unpublished report: $6-8.1981$.

[5] Carter Center. "Schistosomiasis Control programme," In: Health Programme, 2006. http://www.cartercenter.org./health/ schistosomiasis/index.html; 1-2.

[6] NPC, Censusde Facto. "Vital Statistic," Department of Census and Survey, National Population Commission, P.M.B. 1068, Maiduguri, Borno State, Nigeria. 2006.

[7] Climatic Factors Report. "HydrologyDepartment," Ministry for Urban and Rural Water Supply, P.M.B.1188, Maiduguri,Borno State, Nigeria. 12th June, 2007.

[8] Crewe, W. "The Family Schistosomatidae,"A Guide to HumanParasitology. For Medical Practitioners, H.K. Lewis and CoLtd, London, 10th Edition; 101-106.1977.

[9] Crop Production. "Extension Services Report,"Ministry of Agriculture and Natural Resources, Musa Usman Secretariats, Maiduguri, Borno State, Nigeria.1990.

[10] Despommier, D.D. and Karapelou, J.W. "FamilySchistosomatidae," Parasites Life Cycle, Springer Verlag, New York, Berlin, Heidelberg, London, Paris, Tokyo, Revised Edition;76-77.1987.

[11] Ferly, John. "Schistosomiasis,"The Biology of Infectious Disease, (NSCI 102), Schistosomiasis, Cambridge World History of Human Disease, Cambridge University Press, 1993, In: Section viii, 124 of Kipple Kinneth F. edition; 992-997.1993.

[12] Frank, O. and Richard, Jr. "The Technical Director on Schistosomiasis Control," Schistosomiasis, Humbio103/Parasites,2006.

http://www.Stanford.edu/class/humbio103/parasites20 06/schistosomiasis/2.html;1-6.

[13] Gazette of Geographical Location. "Borno State Geographic al Gazette," Department of Land, Ministry of Land and Survey, P.M.B. 1081, Maiduguri, Borno State, Nigeria. 2004. 
[14] Gwana, M.A. "Bilharziasis," Personal Communication, In: The prevalence of $S$. haematobium among Children Attending Primary School in Bama Local Government Area, Borno State, An unpublished Final Year Project; 29 32.1997.

[15] Kanwai,S.A., Ndams,I.S., Kogi, E.I., Abubakar, J.S.,Gyam, Z.G., and Bechemagbor, A. 'Cofactors Influencing Prevalence and Intensity of Schistosoma haematobium Infection in Sedentary Fulani Settlement of Dumbi Dutse, Igabi Local Government rArea, Kaduna State, Nigeria" Science World Journal, 6 (2): 15 - 19. 2011.

[16] Kings, C.H. "Parasites and Poverty: The Case of Shistisomiasis." Acta Tropica; 113: 95 - 60. 2010.

[17] Kings, C.H. and Adel, A.F. Mahmoud. "Schistosomiasis," The biology of Infectious Disease, (NSCI 102 Leaf 27), Schistosomiasis, In: Chapter of Guerrant, Richard L.; David,H. Walker and Peter, F.Weller. Tropical Infectious Disease, Principles, Pathogens and Practice, Philadelphia, Churchill, Living Stone, 1031-1032. 1999.

[18] Martin, K. "Various Fresh Water Snails," SubclassPulmonata, Family Planorbidae, In: FreshWater Mulluscan Snails. 2006..http://www.applessnail.Net/content. snails various.php.

[19] Nanvya, T.N., Dakul. D.A., and Mwansat, G.S."Schistomiasi s in Ndinjor District of Langtang North Local Government Area of Plateau State, Nigeria." Nigerian Journal of Parasitology, 32 (2): 209 - 214. 2011.

[20] N.C.W.R.C. "North Carolina Wildlife Resources Commission," Guidance Memorandum to Address and Cumulative Impacts to Aquatic and Terrestrial Wildlife and Water Quality, In: Wildlife Species; 2006. http://www/ncwildlife.Prg/pg07wildlifespeciescon/pg<3/impacts.pdf.

[21] Ogbe, M.G. "Schistosomiasis (Bilharziasis). An Ancient Water Borne Disease That Occurs in Some Our Communities" The Zoologist; 1 (2): 91 - 104. 2002.

[22] Okali, C.G., and Iwuala, M.O.E. "The Prevalence, Intensity and Clinical Signs of Urinary Schistosomiasis in Imo State, Nigeria" Journal of Helminthology; 78: 337 - 342. 2004.

[23] Okpala, H.O., Agwu, E., Agba, M.I., Chimezie, O.R., Nwobu, G.O., and Ohihoin, A.A. "A Survey of the Prevalence of Schistosomiasis Among Pupils in Apata and Laranto Areas in Jos, Plateau State, Nigeria." Online Journal of Health Allied Science; 1: 1 - 4.

[24] Rober, L. and Cirillo, Jr. "An article on Schistosomiasis", Medicine Schistosomiasis; 2001. http://www.emedicine.Com.Radio/topic1.htm.

[25] Pietro Caramella, M.D. "Schistosomiasis," Intestinal Helminths and Liver Parasites; 2001 http://www.edfound.Toit/HML/sch1.htm.

[26] Rudge, J.W., Stothand, J.R., Basanez, M., Ali, F.M., Khamis, I.S., Khamis, A.N., and Rollinson, D. "Micro Epidemiology of Urinary Schistisomiasis in Zanzibar: Local Risk Factors Associated With Distribution of Infections Among School Children and Relevance For Control." Acta Tropica; 105: 45 - 54. 2005.

[27] Sulyman, M.A., Fagbenro - Beyioku, A.F., Mafe, M.A., Omotola, B.D., Adedoyin, J.A. and Akande, D.O. "Scistosoma haematobium and Concurrent Parasitic Infections in School Aged Children." Nigerian Journal of Parasitology; 30 (2): 79 - 85. 2009.

[28] Ugbomoiko, U.S., Ofaezie, I.E., Okoye, I.C. and Heukelbach, J. "Factors Associated With Urinary Schistosotomiasis in Two Peri - Urban Communities In South western Nigeria."Annals of Tropical Medicine and Parasitology; 104 (5): 409 - 419. 2010.

[29] Van der Werf, M.J., de Vlas, S.J., Brooker, S., Looman, C.W.N., Nangelkerke, N.J.D., Habbema, J.D.F. and Engels,D. "Quantification of Clinical Morbidity Associated With Schistosomiasis Infection in Sub - Saharan Africa" Acta Tropica; 86: 125 - 139. 2003.

[30] W.H.O. "Prevention and Control of Schistosomiasis and Soil Transmitted Helminthiasis" W.H.O. Technical Report Series 912, Geneva. 2002. 